\title{
Anna Zielińska* and Felicja Księżyk Language shifts in the language biographies of immigrants from Upper Silesia residing in Germany
}

https://doi.org/10.1515/multi-2019-0127

\begin{abstract}
The main objective of the article is to illustrate how language ideologies and language management at the macro-level (state language policy), micro-level (in families) and meso-level (local communities) influence language change and the conceptualization of multilingualism of immigrants from Upper Silesia residing in Germany. Language biographies of persons from Silesia demonstrate the significant influence of historical and political events on sociolinguistic processes. Original fragments of biographical interviews of the people surveyed constitute an integral part of the text.
\end{abstract}

Keywords: language shift, language ideologies, language management, language biographies, Upper Silesia

\section{Introduction}

This article presents language biographies of immigrants from Upper Silesia who resides in Germany. Its main objective is to illustrate how language ideologies and language management affect language change. Language ideologies are defined as "any sets of beliefs about language articulated by users as a rationalization or justification of perceived language structure and use" (Silverstein 1979: 193). Language management is broadly understood as a "behavior-toward-language" (Fishman 1971; Nekvapil and Sherman 2015: 1; Nekula in press). It encompasses decisions and behavior pertaining to language, which result in changes in its structure and use. Changes can be initiated by various actors, both those associated with the authorities, and ordinary language users. Developing this theory, Nekvapil and Sherman stressed the relationship between top-down language management organized by authorities, and bottom-up language management at

*Corresponding author: Anna Zielińska, Institute of Slavic Studies PAS, Warsaw, Poland, E-mail: azielinska@ispan.waw.pl. https://orcid.org/0000-0002-0497-4916

Felicja Księżyk, Department of Philology, Opole University, Opole, Poland, E-mail: ksiezykf@uni.opole.pl. https://orcid.org/0000-0002-6913-0108

๖ Open Access. @ 2020 Anna Zielińska and Felicja Księżyk, published by De Gruyter. (co)BY This work is licensed under the Creative Commons Attribution 4.0 International License. 
the level of the family, or individual decisions and actions. They observe that the top-down and bottom-up metaphors make it possible to describe more complicated situations than macro- (state policies) and micro-policies (local policies and activities of families and individuals), because individual actions are often associated with those organized by authorities (Nekvapil and Sherman 2015: 2).

This article presents the results of studies into German-Polish bilingualism, jointly conducted within the project entitled Language across generations: Contact induced change in morphosyntax in German-Polish bilingual speech by the Institute of Slavic Studies, Polish Academy of Sciences, and the University of Regensburg. In 2018-2019, numerous field studies were conducted in Upper Silesia which was incorporated into Poland in 1945, and in Germany, among immigrants from the same area. The study covers bilinguals from two generations:

(1) An older generation who live in Poland, in the territories that belonged to Germany until 1945. These informants were born before 1945 and the majorities were born in the 1930s.

(2) A younger, middle-aged generation of people born in Poland in the 1950s and 1960s in the same territories, who currently live in Germany. They emigrated in the 1970s, 1980s, 1990s.

The study examines bilingual people from these two generations. They have the same linguistic and cultural origins but now live in linguistically different contexts. Their language biographies are closely related to historic events, such as World War II and the profound socio-political transformation in post-war Poland.

By October 2019, the language biographies of 124 bilinguals had been examined, including 20 research participants living in Upper Silesia and 28 research participants born in Upper Silesia and living in Germany at present. Language biographies of the speakers from the latter group are analyzed in this article. They were born in the years 1947-1974 in the prudnicki, kędzierzyńsko-kozielski, raciborski, krapkowicki, zabrzański, opolski, tyski, nyski, świętochtowicki, chorzowski, piekarski, siemianowicki and bielski districts. For around 30 years, they have been living in Germany, in towns and villages in North Rhine-Westphalia, RhinelandPalatinate, Baden-Württemberg, Bavaria, Hamburg and Schleswig-Holstein. They are all Catholics. The interviewees were selected based on the manner and period of their language acquisition, their origins in Upper Silesia, and having lived in Germany for approximately 30 years. The interviews were carried out in a maximally natural setting, most often in respondents' homes. The conversation started spontaneously in one of the languages, but after an hour the researcher switched the language so that $1 \mathrm{~h}$ of the interview was in German and $1 \mathrm{~h}$ in Polish. In response, the interlocutor also switched languages. The respondents did not seem to perceive this situation as artificial as they did not comment on this switch to the 
other language. Thus, all the respondents were interviewed in two languages, Polish and German. Interestingly, some respondents engaging in code-switching in their interviews in Polish, using Silesian words, and sometimes Silesian grammatical structures and phonetic features. These interviews were semiorthographically transcribed accounting for the Silesian influences on their statements in Polish. The interviews will be incorporated into a large multi-media corpus of Polish-German bilingualism collected as part of the Language across generations: Contact induced change in morpho-syntax in German-Polish bilingual speech project. The corpus will include audiotexts and their transcriptions from the entire area incorporated into Poland in 1945, as well as from different places in Germany. It will include long statements by Polish and German bilinguals. The corpus will be multimodal, combining audio recordings with transcriptions, allowing corpus users to encounter the original speech of bilingual speakers.

\section{Theoretical foundations of language biography studies}

A language biography is the story of the acquisition and use of languages throughout a person's life, taking into account the successive phases of life (childhood, youth, adulthood, old age) and events that have influenced the change in that person's language. Language biographies are reconstructed on the basis of narrative interviews in which multilingual persons talk about their experiences related to different languages (Franceschini and Miecznikowski 2004: XII). The essence of studies on language biographies is to see language phenomena from the perspective of the speakers, especially their subjective experiences, emotions, as well as wishes, desires, fears and perceptions related to language (Busch 2013: 17, 2016: 2). A multilingual speaker is the object of study and its central category. The linguistic reality is presented from their individual perspective in the first person (Busch 2013: 8-9, 2016: 5).

The method of biographical interview, which is the origin of language biography studies, is part of the paradigm whereby the subjective vision of the world of the investigated persons is examined, i.e., the anthropological paradigm of emic rather than etic. The emic attitude applied in anthropological studies originates from the concept of the humanistic factor developed by Florian Znaniecki, the founder of humanistic sociology and co-author of a study entitled The Polish Peasant in Europe and America (1996 [1918-1920]), which was fundamental for the sociology of labor. The procedure of the open interview is explained in the book L'entretien compréhensif (2016) by Jean-Claude Kaufmann, who refers to Anselm 
Strauss's grounded theory, ethnomethodology, Max Weber's sociology of understanding and Pierre Bourdieu's works. Kaufmann argues with the classic interpretation of sociological methods which devalues qualitative methods, focusing on quantitative methods and surveys instead. The study of language biographies under the above-mentioned project refer to Kaufmann's concept.

While the biographical turn dates back to the early 1980s, linguists carried out studies within this research paradigm even earlier. The first studies of biographical material by linguists examined the development of bilingualism in their own children in the first half of the twentieth century (Leopold 1939-1949; Ronjat 1913). In 1934-1935, Halina Turska conducted sociolinguistic field research in Poland, in the Vilnius area (today, this territory is in Lithuania). Based on biographical interviews with the representatives of three generations of inhabitants of many villages, she found that the Polish-language areas had emerged as a result of a language change which took place in the young generation of Lithuanian peasants at the beginning of the second half of the nineteenth century (Turska 1995: 34). Women played a leading role in the process of language change (Turska 1995: 35). Halina Turska can therefore be considered a forerunner of the studies on language biographies and historical sociolinguistics. Linguists have also used their own experience of bilingualism as a topic of academic reflection, as shown by the articles by Anna Wierzbicka $(1990,1997)$. This linguist, an emigrant from Poland living in Australia, analyzes her own bilingualism, which she sees as living in two worlds. The experience of one's own bilingualism has also become a literary theme in the famous book Lost in Translation: A Life in a New Language (Hoffman 1998) by an American writer from Kraków, Eva Hoffman. The author describes the development of her own bilingualism related to emigration. Studies are developing with particular intensity in German-speaking countries, where they are based on sociological works, primarily those of Fritz Schütze (1983 among others), Martin Kohli (1981 among others) and Gabriele Rosenthal (1995; 2006). The results of studies on language biographies in various parts of the world are presented in the monograph by Johanna Miecznikowski and Rita Franceschini (2004).

Language biographies are the life stories of multilingual speakers. For example, Michał Głuszkowski presents the language biographies of bilingual Russian Old Believers living in Poland in the Suwałki-Sejny region (Głuszkowski 2011). He describes language biography as the whole of the development stages relevant to the particular idiolect of a person. He analyzes the psychosociolinguistic development of the individual, including subsequent stages of their life (Głuszkowski 2011: 127). The same current is represented by Katharina Meng's works on the Russian Germans (Meng 2004). Language biographies are constructed on the basis of data contained in interviews, participant observations and field study notes. According to Meng, a language biography is a systemic 
presentation of a person's linguistic development divided into the subsequent stages of their life and taking into account the social context. Within this research approach, particular attention is given to the processes related to the acquisition, use, change and loss of languages in a politico-social context. Each of these processes can be observed, on the one hand, in the individual phases of one's life and, on the other, in the social space, which can be divided using the domain method (e.g., family, neighborhood, religion, work, etc.) (Fishman 1964). It is usually assumed that family is the central domain, as it is the first language environment of every person.

\section{The history of Upper Silesia}

The language biographies of immigrants from Upper Silesia are greatly influenced by historical and political events. Upper Silesia is a heterogeneous multicultural and multilingual region that is today situated in both Poland and the Czech Republic. It is the part of Silesia located on the Upper Oder, and in Poland it encompasses the areas around cities such as Opole, Racibórz, Koźle, Głubczyce, Gliwice, Bytom and Katowice. Over the ages, its dynastic and political borders, alongside statehood, have changed many times. In the nineteenth century, most of it belonged to Prussia, which is why it was incorporated into a united Germany in 1871. After World War I, Upper Silesia was in the territories of three countries: the German Reich, the Republic of Poland and Czechoslovakia (Linek 2015: 379). The beginnings of the distinction between Lower and Upper Silesia date back to the fifteenth century. In the eighteenth century, Upper Silesia, where a Silesian version of the Polish language was spoken, began to stand for backwardness in German discourse, as a result of religious (Upper Silesians are mostly Catholics) and linguistic differences (Linek 2015: 380-381). During the long period of Silesia being incorporated into the German state, German use increased significantly, also entering those language domains where Silesian was previously dominant. What was important in this respect was that Polish was removed from schools, and compulsory teaching in German was introduced in 1872, which resulted in a gradual increase in bilingualism even among the rural population, who previously would often speak only Silesian (Choroś 2015: 70; Matuschek 1997: 110).

As a result, Upper Silesians from regions in the east were usually bilingual and spoke both German and Silesian. For the studies carried out as part of the project, the period after World War II is significant, when Silesia (previously part of Germany) was incorporated into Poland. From the turn of 1944/45, the remaining German population and German language was the target of a repressive policy of the Polish state and supported by the Polish community. In the post-war years, 
Poles wanted to retaliate and obtain compensation for the harm they had suffered during World War II. It was widely believed that Germans should be interned and displaced, and that German should be eradicated (Kacprzak 2010: 215). Shortly after the war, about three million Germans were displaced from Poland and only qualified specialists were kept who were needed in industry. People who could prove the Polish origin of their families were also allowed to stay; however, all of them underwent cultural and linguistic polonization (Madajczyk 1998: 66-67). The campaign to erase everything that was German was carried out by regional authorities in all areas incorporated into Poland, but it was the most intensive in the Sląskie Region (Kacprzak 2010: 230), which before 1950 also comprised the majority of today's Opolskie Region - the pre-war Opole district. In order to determine who was Polish and who was German, the nationality of the indigenous population from the territories incorporated into Poland was investigated. Speaking Polish was one of the decisive criteria for Polishness, sometimes limited to the knowledge of the text of a prayer (Kneip 2000: 164; Madajczyk and Berlińska 2008: 549). Madajczyk and Berlińska observe that "borderland communities were treated instrumentally - the incorporation of Silesians and Masurians into the Polish nation served as an additional argument to legitimize the shift of the western border" (Madajczyk and Berlińska 2008: 240). Following the trend to establish nation-states, the authorities emphasized the de-germanization of the incorporated areas, that is the removal of all traces of German, consisting of the massive polonization of names and surnames, the ban on German names, the elimination of German from public and private life, the removal of traces of German culture in the form of German names, inscriptions, tombstones, and the destruction of German books. All forms of association with the German culture and people were persecuted by various sanctions - fines, detention, imprisonment in camps, dismissal from work or resettlement to Germany (Linek 1997: 74). According to Madajczyk and Berlińska, "the removal of German traces had the intended effect at the turn of 1948/1949. Although not entirely removed, they were no longer a visible part of the cultural landscape" (Madajczyk and Berlińska 2008: 564). After massive displacements to Germany immediately after the war, the population structure continued to change in Silesia. New inhabitants settled down in Silesia, mainly from the former Polish eastern regions incorporated into the Soviet Union, as well as settlers from other parts of Poland destroyed during the war. Apart from the tens of thousands of Germans needed in industry, Lower Silesia became inhabited by an entirely immigrant population, while the Silesian population, which identified as Polish during the verification operation, remained in Upper Silesia (Karch 2018: 274, 290). The newcomers lived here alongside the former residents (Karch 2018: 287; Madajczyk 1998: 67; Madajczyk and Berlińska 2008: 524). The new inhabitants were generally hostile towards the Upper Silesians, clearly considering 
them to be Germans. The social situation of the indigenous inhabitants of Upper Silesia was therefore very difficult. This, along with various other reasons (family reunion, financial situation, nationality), increased their desire to leave Poland. In 1949-1954 alone, almost 100,000 people left Poland for Germany under the family reunion campaign (Madajczyk 1998: 87). The number of immigrants remained high in the years that followed: "By February 1959, 253,130 people had left, including all the intelligentsia" (Madajczyk 1998: 95). In the 1970s, pursuant to the GierekSchmidt agreement, another 120,000-125,000 persons were permitted to leave for Germany in exchange for a business loan granted to Poland. Over 47,000 people left for Germany from the Opolszczyzna alone. The name Opolszczyzna refers to the Opole Region (Pl.: województwo opolskie). It spread after World War II and the influx of persons displaced from the Eastern Borderlands (Linek 2015: 382). The wave of departures grew stronger again starting in mid-1981 (Madajczyk 1998: 104-108). This is the period (the 1980s and early 1990s) when most of the respondents interviewed in this article left Poland. A total of over 1.5 million people used the opportunity to leave for Germany between 1950 and 2005 (Lasatowicz and Weger 2008: 149).

The immigrants from Upper Silesia form part of a very large group named Aussiedler in German law, in accordance with the German Federal Law on Expellees (Bundesvertriebenengesetz, BVFG) (Dietz 2011). This term is explained by Barbara Dietz:

The term Aussiedler was coined in the early 1950s as the influx of German minorities from east-central and southeastern Europe and the Soviet Union continued after the flight and expulsion during the immediate postwar years had come to an end. The Constitution of the Federal Republic of Germany (Article 116, paragraph 1) guarantees the admission of these persons as German citizens: 'Unless otherwise provided by a law, a German within the meaning of this Constitution is a person who possesses German citizenship or who has been admitted to the territory of the German Reich within the boundaries to the territory of December 31, 1937 as a refugee or expellee of German ethnic origin or as the spouse or descendant of such person.' Decisive for admission as Aussiedler are the 'German ethnicity' of the immigrants and the 'expulsion pressure' in their county of origin” (Dietz 2011: 245).

Immigrants from Upper Silesia being included in the group of Aussiedler is fundamental for the topic of the language shift discussed here. The German policy towards Aussiedler aimed at their complete integration into German society:

Since the beginning of the immigration of Aussiedler, it was a political goal in Germany to ease and promote the integration of this group, something that had already been laid down programmatically in the immediate postwar period for refugees and expellees. Along with the granting of German citizenship to Aussiedler, this attitude led to the privileged admission of this group of immigrants (Dietz 2011: 248). The actions promoting the integration of this group include considerable social support and financing language courses. Even though the 
financial means earmarked for the integration of Aussiedler dwindled in the 1990s, this group was socially and financially privileged compared to other immigrants (Dietz 2011: 248).

In our project, we do not use the category of ethnicity essential to the definition of the Aussiedler, and neither do we use the categories of nationality. The Silesian identity is a complex structure which is examined via the interviews (Księżyk in press). For the same reason, we also do not use the term Aussiedler, which was created for political purposes, but prefer the more general term immigrants.

\section{Language change in Upper Silesia after 1945}

Even before the 1945 border shift, many inhabitants of Upper Silesia knew Silesian, but it was not widely spoken, especially in the cities. The extent to which it was spoken depended also on individual factors, such as origin, occupation or social group (Kneip 2000: 160). The statements in the interviews we collected show that Silesian can be considered a separate language, e.g.,:

(1) Actually, most [students] in this [school] were from the rural areas, from the surrounding villages, and they also spoke Silesian, that is our dialect, it was neither German nor Polish. [Original version: Eigentlich war in der Dings war Mehrheit war aus der Dorfe umliegende Dorfe und die haben auch Schlesisch gesprochen also schon unsern Dialekt, es war auch kein kein Deutsch und kein Polnisch.] (SO_LAM)

Silesian is sometimes called Wasserpolnisch - 'diluted Polish' in German. Yet, some respondents do not make a distinction between Silesian and Polish in their accounts, which creates interpretational problems.

Current studies on Silesian indicate an increasingly clear trend of Silesian becoming emancipated and officialized. Nevertheless, the attempts to include Silesian in the Law on national and ethnic minorities and regional languages (Ustawa o mniejszościach narodowych i etnicznych oraz o języku regionalnym) have so far been futile (Michna 2019: 59). While scholars are divided on the matter of the officialization of Silesian, the idea of an independent Silesian ethnolect has been winning supporters among linguists and sociologists. Speakers of Silesian are also becoming increasingly convinced of the fact that Silesian is an entity independent from Polish (Jaroszewicz 2019a: 141-142). In the latest census, over 500,000 people living in Poland indicated Silesian as a language used at home (Gudaszewski 2015: 69). Silesian was also the main mother tongue indicated by the interviewees (140,000), second only to Polish (Gudaszewski 2015: 82; Kamusella 2016: 90). The proponents of the officialization of Silesian emphasize objective conditions in 
favor of elevating Silesian to the level of a language, such as the fact that the Silesian ethnolect has been listed as a separate entity on the official list of languages acknowledged by the International Organization for Standardization; they also indicate that Silesian operates in a majority of functional language areas, which definitely goes beyond the framework of dialectal creativity, and to the standardization and codification attempts taken with respect to Silesian in the Cieszyn principles of Silesian orthography (Jaroszewicz 2019b: 27, 32; Michna 2019: 59; Wyderka 2018: 9). Given the above, the fact that Silesian has not been recognized as an official language is interpreted in political terms (Kamusella 2016: 109). However, Hentschel takes a neutral position on this matter and recommends that Silesian be treated as a (regio-)lect, thereby supporting the use of a politically neutral term, and argues that Silesian is transforming into a micro-language, thus being neither a prototypical dialect nor a prototypical language (Hentschel 2018: 43, 62).

Our interviews showed that there were differences between the families from cities/towns and rural families. People from urban environments (Gogolin, Klodnitz [now Kłodnica], Oberglogau [now Głogówek], Proskau [now Prószków], Oppeln [now Opole]) frequently mentioned that, before 1945, their families and surroundings spoke only German, and their family members did not come into contact with Polish or Silesian until after the war, although some respondents believed that their parents might have known Silesian. They were therefore monolingual. In contrast only a few inhabitants of rural areas reported that they were monolingual (for example Himmelwitz [now Jemielnica], Bierdzan [now Bierdzany], Josefsgrund [now Józefów], Norok [now Narok]). The rural population was mostly bilingual. They reported that before World War II, they spoke Silesian at home (Niesnaschin [now Nieznaszyn], Comprachtschütz [now Komprachcice], Mechnitz [now Mechnica], Groß Döbern [now Dobrzeń Wielki], Trawnig [now Trawniki], Straduna [now Stradunia], Friedersdorf [now Biedrzychowice]), while German was spoken in official domains. All the villages mentioned here, where our respondents come from, lie east of the line drawn by Wiesinger and showing the extent of the Polish language before World War II. The inhabitants of these villages, similar to our interviewees, were mostly bilingual, while the population west of the marked language border was mostly monolingual and spoke German dialects (Księżyk 2017: 24; Wiesinger 1983: 818). This is evidenced by the biography of one of our informants (XL_MÜN). By the age of six, that is until 1970, he lived in the village of Biedrzychowice where people spoke Silesian, although everybody knew German:

(2) Here people spoke Wasserpolnisch in their day to day lives. [Original version: Ten Wasserpolnisch wurde hier alltäglich dann gesprochen.] (XL_MÜN) 
He knows this from the tales of his uncle, who lives in Berlin at present. This was the case both during the childhood of this informant and the pre-war times. This statement is confirmed by a local history researcher, Johannes Preisner, who quotes the census which shows that the majority of the rural population was bilingual at the beginning of the twentieth century: "In the census of December 1, 1910, there were 164 inhabited houses and one uninhabited building and a population of 1,233 persons in Friedersdorf. Of these 520 were male and 713 were female. [...] Among the people in the census, 51 spoke only German, 307 only Polish and 875 spoke both German and Polish. 12 persons were of Slavic nationality, who came from Galicia and Russia” (Preisner 2009: 123). Interestingly, compared to 1905, the number of Polish-speaking monolingual persons dropped significantly, while the number of bilingual persons almost doubled (Preisner 2009: 124). In the following part of the interview, the informant XL_MÜN admits that it was different in the town of Głogówek, to which the informant moved when he had turned six. German was spoken there, though the indigenous people also understood Silesian. From the stories of his mother, who worked as a shop assistant for some time, he knows that German was often spoken in Głogówek even after 1945 (in the 1950s). This is also confirmed by an analysis of the comments made by the authorities in the 1950s, in which Głogówek often appears in connection with the use of the German language there and was even named 'second Berlin' (Dawid 2020: 368).

Repressions against speaking German, and the ban on teaching German in schools in the opolskie and katowickie regions (names of regions as in the 1950 administrative division) which was in force until 1989, thoroughly changed the linguistic situation in Upper Silesia. For fear of sanctions and discrimination, German was no longer used, and was replaced with Silesian or Polish. This is illustrated by the accounts of the interviewees who point out that in families with many children the language sometimes changed within a few years. Therefore, older children were still socialized in German, and their younger siblings were raised speaking Silesian or Polish. This is shown in several interviews:

(3) And my sister, she spoke German quite well, the older one. Because they still taught her, so they still had to talk. [Original version: A moja siostra ona umiała jeszcze dość dobrze po niemiecku, ta starsza [...] no bo ja jeszcze uczyli, to jeszcze wtedy musieli gadać.] (KI_WIM)

(4) So my sister and I always talked in Polish, because she also, when we were little, we didn't speak so much German, because she was five years younger, and we just talked with her only in Polish then. [Original version: Also haben wir immer gesprochen Polnisch mit der Schwester, ja weil die hat auch, wo wir 
klein waren, haben wir nicht so viel Deutsch gesprochen, weil da war schon die fünf Jahre ä jünger und mit der haben wir jetzt halt nur Polnisch gesprochen.] (LX_GEM)

The following fragment of the interview also shows the quick change from German to Polish or Silesian:

(5) My father remembered only a few words in German, but he always said that as a little boy, as they spoke German, someone was just standing outside the window. Then they knocked on the door and his grandmother had to pay fines, and, you know, there was no money for that, so you had to start speaking Polish. [Original version: Mój ojciec tylko pamiętat parę słów po niemiecku, ale zawsze mówit, że jako mały chłopczyk, jak mówili po niemiecku, to po prostu za oknem ktoś stał, wtedy się pukało do drzwi i mu babcia musiała płacić kary pieniężne, wtedy wiadomo na to pieniążków nie było, więc trzeba było zacząć mówić po polsku.] (LO_LAM)

The breaking of the language continuum in families was a consequence of topdown language management. It should be firmly emphasized here once again that the break in the generational transmission of German was not a voluntary act rooted in one's attitudes, but the outcome of a brutal anti-German policy enforced by the Polish state (Kamusella 2011: 773). This policy was highly effective, as the use of German was discouraged by the establishment of camps for the Germanspeaking population (Karch 2018: 259, 276-278; Madajczyk and Berlińska 2008: 273-309). One such camp operated in Gliwice from 1947 to 1949. People could find themselves in the camp for merely speaking German (Linek 2000: 363-367). Our interviewees can still recall their families suffering harsh penalties for speaking German:

(6) I know it in detail. When my father, Helmut and Horst went to a pub, to that old pub there, it was normal when they had had a few beers that they would begin to sing in German, because they could not sing in Polish, because in elementary school [they learned in German only], so the police arrived and [they were tried by] a local court. It would cost you some five hundred zlotys [a fine] at the time, but this was a lot. There were those [people] calling [the militia to inform them] that people were singing in German. [The militiamen] came then and ... and they paid a fine. [Original version: Bo ja wiem dokładnie, jak tu jak tutaj ojciec, mój ojciec tu Helmut i Horst tu z tygo oni przeważnie jak poszli do knajpy jeszcze tu tej starej knajpy jeszcze nie tam wszyscy chodzili, normalne było, jak wypili se pare piwek i spiewali zaczli śpiewać po niemiecku, bo po polsku nie umieli śsiewać, bo w szkole 
podstawowej, no to przyjechała policja i kolegium, nie. To się płaciło tam może pięćset złoty kiedyś, ale to było dużo nie. Byli tacy, $\dot{z} e$ dzwonili, $\dot{z} e$ śpiewaja po niemiecku, przyjechali i i wtedy płacili mandat.] (BN_WUP)

The older generation, those born before 1945, possess more vivid, and frequently more painful memories.

(7) Well, we couldn't speak German here, those were hard times then. My uncle returned from Russian captivity in '48, it was in '48-'49, around that time, and they talked in German here, in this room, and a man was standing under the window, his name was $K^{*}$. And he went straight to the militia, they were nearby. There was a militia station here. So they entered [and said that] everybody [had to go] to the station. And then my parents had a trial before the municipal court in Koźle. They had to pay a fine and it's also written in the sentence that they spoke German in their own apartment. [Original version: Ja hier durften ja wir nicht Deutsch sprechen. Es war schlimme Zeit damals. Mein Onkel der kam achtundvierzig aus der russischen Gefangenschaft, das war achtundvierzig neunundvierzig so in dieser Zeit na und da haben sie hier in dem Zimmer Deutsch gesprochen. Da stand unter dem Fenster ein Mann, er hieß $K^{*}$ damals ne und ist gleich um die Miliz gegangen, die Miliz war ja hier nicht weit ne, hier war der posterunek von der Miliz no. Da sind sie reingekommen alle raus in den posterunek rein dort und dann haben auch meine Eltern einen Prozess gehabt im sąd grodzki in Cosel, mussten Strafe zahlen und es ist aufgeschrieben auch auf den na wyrok ja Urteil, dass sie gesprochen Deutsch gesprochen haben in eigene Wohnung ja.] (LU_KOŹ)

(8) Well, we talked a lot in German, also when all our uncles and aunts were here, but you had to be very cautious and once we went with all my father's family to Opole to do shopping before Christmas and we ended up in a little restaurant. And my father and uncle came across a friend from Opole, and they talked in Polish and Silesian but there were also words in German, and my father was detained. He [had to go the a militia station] to get his ID back and they held him and he was [held] in the cellar at the militia station. For a long time I had no idea that this had happened but after some time he told us about what he had gone through there. He told us what he had gone through there in the water, standing in the water up to his legs, and we had a great number of German books then but we had a tiled stove in the apartment so we fed all these books to the tiled stove. [Original version: Ja wir haben viel Deutsch gesprochen und auch noch wie die ganzen Onkel und Tanten hier waren [...] aber man musste sehr aufpassen [...] und es war ja mal so ein wir 
sind die ganze Familie so aus dem Vaterseite die Tanten und wir waren mal einmal in [...] Oppeln Einkäufe machen vor Weihnachten [...] und dann sind wir gelandet in ein kleinen Restaurant und [...] mein Vater und der Onkel die trafen noch einen Freund aus Oppeln [...] und die sprachen Polnisch Schlesisch, aber sind Wörter gefallen auch in Deutsch und mein Vater haben sie eingesperrt der [...] musste sein dowód osobisty [...] er musste seinen Ausweis abholen und die haben ihn gelassen und da war hier im Keller in der Polizei lange habe ich das nicht gewusst, aber dann nach einer Zeit hat er sich dann ausgesprochen, was der dort so erlebt hat im Wasser [...] mit den Beinen im Wasser [...] und wir in der Zeit [...] wir hatten sehr viele deutsche Bücher, aber wir hatten dort Kachelöfen in der Wohnung also und die Bücher sind gelandet im Kafelofen.] (SL_OPO)

German became a secret language used by the older generation to talk about topics not intended for children. This is evidenced by the statements:

(9) It was like that, I think, it was like in most families, if they wanted to keep a secret from us or something, they spoke German, no, that is, they spoke Polish to us, that is [they talked] more in Silesian, well in a dialect, and if they wanted to keep a secret from us or something, I don't know exactly, I often heard that they spoke German then. [Original version: Das war so, also ich glaub das war so wie in meisten Familien, wenn die wollen was von von uns verschwiegen oder so, da haben die dann Deutsch gesprochen, ne, also zu uns oder so haben sie Polnisch gesprochen, also mehr Schlesisch, also Dialekt und wenn die wollen dann was verheimlichen oder so oder weiß ich nicht genau, da hab ich hab ich oft gehört, dass die haben dann Deutsch gesprochen.] (SO_LAM)

(10) [Parents spoke German] when they wanted to keep a secret from us. [Original version: [Rodzice mówili po niemiecku] jak mieli coś do zatajenia przed nami.] (KL_BIE)

(11) That is, they [parents] spoke Silesian all the time, they only spoke German when they didn't want us to hear, no. [Original version: Also po ślasku godali cały czas, po niemiecku yno godali, jak chcieli, żeby my nie styszeli, ni.] (KI_WIM)

Using German as a secret language was practiced in many families, including other regions in western Poland. Such a specialization of language function is a symptom of breaking the generational language continuum in families. 
In some families, children were taught prayers in German, but in later years they no longer prayed in German:

(12) They tried [to teach me prayers in German], when I was little, apparently. I don't even remember that, but I know that, for instance, my aunt in Berlin said that when she came to us here, right, I said some prayers in German so prettily, I recited them and so on. And then she came a couple years later and I didn't know anything anymore. I had forgotten everything. [Original version: Spróbowali podobno jak byłem maty nie tam. Już nawet tak tak nie pamiętam, ale wiem, że na przykład moja ciotka w Berlinie mówiła, że jak tu do nas przyjechała wtedy nie, tak tak ładnie po niemiecku mówiłem jakieś modlitwy tam recytowatem i tak dalej, i później tak. A potem przyjechała parę lat później już nic nie wiedziałem. Wszystko zapomniałem nie tam.] (XL_MÜN)

In this context, the change of the language situation in Upper Silesia, also in the religious sphere should be mentioned. Church schematisma (directories) show that in the nineteenth century Polish was used in pastoral work in most Upper Silesian parishes, with the exception of a few districts such as Leobschütz [Głubczyce after 1945] and Grottkau [Grodków after 1945]. The second half of the nineteenth century saw the division into masses and services celebrated in the Polish or German language in many parishes (Kurpiers 2015: 73). This allowed the congregation to participate in services corresponding to their language competences and preferences. National languages at that time were used for praying and singing, because the masses were celebrated in Latin, which did not change until after the Second Vatican Council in the 1960s. Especially after Hitler came to power in 1933, the use of German in the parochial ministry systematically increased, and in 1939 Polish was removed from the liturgy altogether (Hanich 2008: 52-53). Another radical unification of the language used in pastoral ministry took place in 1945, when the Polish state authorities ordered the Church to celebrate services exclusively in Polish. The ban on the use of German in the religious sphere was particularly strict in the villages and towns where the population spoke Silesian (Hanich 2008: 61-63). This caused extraordinary difficulties for both the population and priests attached to specific rites. This is illustrated by the following quote:

In Szymiszów, Strzelce Opolskie district, in May 1945, during the mass the priest announced in Polish which songs would be sung (three in Polish and two in Latin). Yet the young people sang two songs that were to be sung in Polish (Jesus, Jesus, come to me and Rejoice, Queen of Heaven) in German, probably not knowing the lyrics in Polish. [...] After the end of 1945, the state authorities made efforts to remove Fr. Dean Leon Szal (another spelling of the name Schall). The priest's problems began on November 11, when he translated the most important points of the pastoral letter to the faithful who did not understand Polish, and read the gospel 
to them in this [German - A.Z., F.K.] language. As he explained, the ban issued by the local authorities in Prudnik in early June applied only to songs and sermons in German. [...] Finally, at the end of 1946, the authorities of the region decided to expel the priest to Germany (Linek 2000: 131).

Our interviewees also say that from 1945 to the 1989 breakthrough it was not possible to use German in the life of the Church. One of the informants admits that the priest preparing him for receiving the First Holy Communion was bilingual:

He, like the Silesians, knew two languages [German and Polish]. [Original version: On tyż tak jak Ślazaki, on umiat dwie szprachy.] (KI_WIM)

He categorically denies, however, that the priest would make use of it:

(14) In Gościęcin in German? They would have crucified him. [Original version: W Gościęcinie po niemiecku? To by go ukrojcowali.] (KI_WIM)

Gościęcin - a parish including Trawniki, the home village of the informant KI_WIM - was a German speech island before 1945. Most of its inhabitants were resettled to Germany after World War II and replaced by the displaced persons from the neighborhood of Lviv.

Another interviewee points out that also priests from Silesian families did not always meet the religious needs of native residents, and the Catholic Church was becoming a national institution:

(15) Anyway, in the Church too. The same [like at school], I was also very very disappointed about their generally clearly unambiguous pro-Polish approach. [Original version: Übrigens auch in der Kirche. Das Gleiche, hab ich das also auch irgendwie auch sehr sehr negativ vernommen, dass man im Grunde ja also auch eindeutig also propolnisch sich immer aufgestellt hatte.] (NT_LÜB)

Such attitudes were related to the fact that "the Polish state treated the Church as an object of national policy" (Linek 2000: 111).

Language macro-management exercised by the state through issuing a ban on the use of German in all spheres, translated into micro-management at the family level, also leading to the elimination of this language.

Admittedly, one of the founders of first German minority organizations in the Opolskie Region, Johann Kroll, claimed that "With Gomułka [Władysław Gomułka - the First Secretary of the Polish United Workers' Party and the actual leader of the country in 1956-1970 - A.Z., F.K.] the polonization pressure eased, people could speak German among themselves, but children were not allowed to learn our language in schools" (Kroll and Kalicki 1991: 130), but it was more common for families to succumb to the pressure and not pass the language on to 
children (Ogiolda 2018: 19). This resulted in a generation gap when it came to knowing German. The opportunity for minority education did not appear until after the 1989 political breakthrough.

The interviews show that the German-speaking families began to use Silesian much more often than Polish. Speaking in Silesian, however, caused further problems. The main goal of the language policy in the whole of post-war Poland was to eradicate dialects. This was associated with political processes pursuing the cultural unification of all inhabitants of the country and ensuring the political, economic and cultural dominance of the ruling elite (Gajda 2001: 209), not only by removing non-Polish elements, but also by eliminating regional differentiation (Kneip 2000: 174). For this reason, the command of the standard Polish language was indispensable for social promotion. After World War II, for the first time in Polish history, a nationwide community was formed that included all classes and social strata, including peasants. A high position in the ethos of this community was attributed to literary language. In the 1940s-1970s, the number of users of this prestigious language variation increased. The massification of literary language in Poland led to internal qualitative changes and transformations in the system of language variations (Gajda 2001). Silesian was tolerated, but its low prestige was stressed at the same time. Speaking Silesian was persecuted in schools first and foremost, in line with the ideology of the linguistic unification of the country. One respondent remembers that students were pressured to refrain from speaking Silesian:

[They taught us] to speak Polish, Silesian was forbidden because it would interfere with education in the future. Because the Silesian language wasn't respected enough? [Original version: Żeby godać po polsku, po śląsku nie wolno, bo to szkodzi później dali w szkołach. Bo śląski język nie jest taki poważany jak, nie?] (BN_WUP)

Failure to comply with language ideologies which privilege majority languages is usually the reason for the negative lived experience of language, associated with shame (Busch 2013: 18-19, Busch 2015). Shame arises when a speaker realizes that they have violated a linguistic or social norm by using a language considered socially unacceptable. Children were made to feel ashamed for speaking Silesian at school, which is evidenced by numerous statements about the language at school, e.g.,:

(17) If we were among ourselves, somewhere on a break, or on a trip, or on a Saturday bicycle tour, we would speak Silesian in private. We were, like, kind 
of ashamed. [Original version: Jeżeli byliśmy między soba, gdzieś na przerwie lub na wycieczce lub $w$ soboty wycieczki rowerowe prywatnie mówito się po ślasku. Raczej byt taki jakby wstyd.] (LO_LAM)

(18) When we moved from this small village of Łężce to Kłodnica in 1979, I had problems with vocabulary when I was little. In Eężce, we spoke only Silesian, and here, this was an urban group and although there were children from Silesian families, they spoke pure Polish. So my mother and I noticed we were being mocked in class. The teachers also reprimanded me if I used a Silesian word or sentence. When they corrected me, the class started to laugh, so my mother also urged my grandmother to either speak Polish with me or not talk to me at all. [Original version: Jak żeśmy się w roku siedemdziesiątym dziewiątym $z$ tej małej miejscowości Łężce do Kłodnicy przeprowadzili, to zauważłam jako dziewczynka miałam problemy ze stownictwem [...] w tężcach żeśmy mówili catkowicie po śląsku [...] a tutaj już była grupa miastowa i chociaż nawet byly dzieci z rodzin śląskich, mówily czysto po polsku, więc moja mama i ja zauważyliśmy, że jesteśmy wyśmiewani w klasie, panie nauczycielki też zwracały mi uwagę, jeżeli użyłam śląskiego stowa lub zdania, poprawiając zaczęła się klasa śmiać, więc moja mama też robiła taki nacisk na babcię, żeby albo zaczęła ze mna mówić po polsku albo nawet ze mną nie rozmawiała.] (LO_LAM)

The same informant said that due to her being Silesian she was harassed in high school by other students and a Polish language teacher:

(19) It was worse in high school. It could be seen, we could actually say we were offended. It was even said: You are from the Goebbels family. It was very hard for me in high school, I had a very, so to say, strict teacher, a patriot, so she paid great attention to that if even a word had been mispronounced. She could even, so to say, tease that you are sixteen and still don't know how to speak correctly in your homeland. [Original version: Gorzej było w szkole średniej. To można było zauważyć, wręcz można powiedzieć bytyśmy obrażane. [...] No nawet było powiedziane: Jesteś $z$ rodziny Goebbelsa. W szkole średniej było mi bardzo ciężko, miałam bardzo taka można powiedzieć ostra nauczycielkę, patriotkę, tak że zwracała wielka uwagę na to, jeżeli nawet jakieś słówko by się niepoprawnie powiedziało. Mogta tak nawet, jak to się mówi dokuczyć, że mając szesnaście lat nie wie się, jak się w swojej ojczyźnie poprawnie mówi.] (LO_LAM)

The above quotation shows that using Silesian was associated with having a German origin, which triggered insults referring to Nazism and war criminals. 
Despite the state's language policy aimed at eliminating Silesian, speakers from Upper Silesia are emotionally connected with it. Silesian is an indicator of Upper Silesian identity, as evidenced by fragments of interviews, such as:

I mean, I am, I see myself as a Silesian, right. And in my perception today, Silesian is my native language, by no means Polish (laughter). [Original version: Also ich bin, ich betrachte mich als Schlesier, ne, und mittlerweile betrachte ich eher hmm, also das Wasserpolnische ist ist meine Muttersprache, auf keinen Fall Polnisch, ne (Lachen).] (XL_MÜN)

Such a positive attitude stems from language meso-ideologies, which are contrary to the state macro-ideology in the Silesian community. Language macro-ideologies should be understood as a complex of beliefs, judgments, and concepts regarding or shaping the perception of languages and their users, which are shared in the area that transcends national, ethnic or linguistic borders. Internalized by persons from different social groups, language macro-ideologies directly or indirectly affect a large part of society. They change over time, but they are long-term structures overall. The macro-ideology in Poland says that people living in one country should have one common language and, vice versa, people who speak one language should have their own country. This is also known as the territorial principle. The territorial principle is an ideology that associates a particular language with a particular land, which produces subordination of other languages (Piller 2016, 35). Language meso-ideologies are spread across narrow social groups, in small areas (Turner 2012). The meso-ideology in Upper Silesia says that Silesians should speak Silesian, and thus there is tension between the top-down language management organized by state and that organized by local, bottom-up management.

\section{Language change after migration to Germany}

While the autobiographical interviews of the people born before 1945 show that their socialization before the end of World War II was either monolingual in German or bilingual - in German and Silesian, the representatives of the generation born after 1945 often did not know German before leaving for Germany. The transmission of German in their families was interrupted to the extent that the people who went to Germany as adults learned German from scratch in language courses, and sometimes they never developed good language skills. This is especially true for people who did not pursue any education in Germany, apart from language courses, as well as for those who live in Silesian endogamous marriages, who usually speak Polish or Silesian at home, and have little contact with German 
due to their occupation. Several examples of how these speakers assess their language competence follow:

(21) And now I can't speak German either. [...] But this is not correct German. Grammar and words or something are still missing. Okay, I can communicate, but I can't say that I speak perfect German or something. [Original version: A jetzt kann ich auch nicht Deutsch sprechen [...] Aber das ist kein kein richtige Deutsch. Es fehlt noch Grammatik und und Wörter oder so. Ja ich kann mich verständigen, aber ich kann nicht sagen, dass ich sprech perfekt Deutsch oder so.] (SO_LAM)

(22) Reading somehow you began to make associations, build sentences, of course this is not perfect, none of us will speak perfect language, we will not have the right accent. [Original version: To czytajac, tak jakoś człowiek zaczą kojarzyć, składać zdania, oczywiście to nie jest perfekt, nikt z nas nie będzie mówit perfekt, nie będzie tego akcentu.] (KL_BIE)

A lack of knowledge of German generated a lot of frustration and problems at the beginning of the interviewees' stay in Germany, e.g.,:

(23) Yes, yes, yes, yes, it was also at the beginning, this language was the worst problem, it was a disaster for me. At the beginning, I studied German at language courses. But when I went to an institution to deal with some official business, eh, some words have a double meaning, and if I misunderstood something I would be so ashamed, if I gave the wrong answer, it would be such a shame for me that I could sink through the floor. It's always cooler when you make mistakes and laugh at them, but I couldn't do that, that was a disaster for me. [Original version: Doch, doch doch doch to też było na poczatku, tyn najgorsza, najgorszy problem to była ta szpracha, to było, to było dla mnie to było katastrofa. Na poczatku myśmy to uczy, jał się uczyłach na kursach językowych tej Sprache, aber jak poszłam do urzędu cojś załatwiać, hmm, bo niektóre wyrazy mają Doppeldeutung i i jak jak bych cojś źle zrozumiała, to mi było so peinlich, falsche Antwort gegeben hätte, to było, to by mi było so peinlich, ich könnte unter Boden mich ver verkriechen. Das ist immer schöner, wenn man Fehler macht und dann lacht darüber, aber ich konnte das nicht, to jest, dla mnie to było katastrofa.] (NF_PAD)

Polish was used in private, and German in external contacts:

Let's say outside, between people or something, it is rather German, and in a closed circle, well, let's say more in Polish. [Original version: Powiedzmy na 
zewnątrz między ludźmi czy cojś to raczej po niemiecku, a jak w zamkniętym gronie, no no powiedzmy więcej po polsku.] (SO_LAM)

In the following fragment of the interview, the informant talking about the use of language in his mother's family home in Upper Silesia draws an analogy to the language practices used in his family in Germany:

(25) It seems to me, just like we all do it here, my mother always spoke, they spoke Polish at home and German on the street, just like we do in Germany. [Original version: Mi się zdaje, tak jak my tu wszędzie, tak moja mama zawsze gadała, $w$ domu godali po polsku, a na ulicy po niemiecku, to tak jak kurcza my w Niymcach.] (KI_WIM)

In endogamous marriages, where both spouses come from Poland, Silesian dominates in their communication, although they also speak Polish and German, in various configurations. Several examples follow.

(26) [I talk to my wife] in various combinations, say, seventy percent in Polish, thirty in German, it's kind of mixed, because it's half a sentence in Polish, half in German. [Original version: [Z żoną rozmawiam] różnie, powiedzmy siedemdziesią procent po polsku, trzydzieści po niemiecku, to jest takie mieszane, bo to jest pót zdania po polsku, pół po niemiecku.] (SO_LAM)

(27) And then we speak with my husband sometimes half in Polish, half in German, half in Silesian, never one hundred percent. [Original version: Und dann sprechen wir manchmal mit meinem Mann auch so halb Polnisch, halb Deutsch, halb Schlesisch, also nichts Hundertprozentiges.] (CL_BIE)

(28) You can also wylyszować this, no, you can löschen it? Wylyszować, after all this is, this is non-Polish, non-German, you can wylyszować, that's how we are trying to simplify this language. [Original version: To idzie te $\dot{z}$ wylyszować, nie, idzie to té் löschen? Wylyszować, das ist ja to tyż jest niepolski, nieniemiecki, idzie wylyszować tak my sp próbujemy tę vereinfachen die die Sprache.] (NF_PAD)

The informant in the last quotation is trying to illustrate how she and her husband talk using the example of the verb wylyszować - 'to delete'. She is integrating the German verb löschen - 'to delete, erase' into the Polish language, attaching the Polish infinitive ending and a prefix wy-. Thereby a hybrid wylyszować emerges, which the speaker classifies as part of neither the Polish nor German language systems. In the opinion of the speaker, by mixing the two codes the spouses are simplifying their communication. 
Multilingualism and language mixing were practiced in everyday life:

(29) For example, our neighbors were from Gdańsk, so I had to take care speaking to them and, to my surprise, I managed in those initial years, I could separate speaking Polish, Silesian and German, sometimes I spoke three different languages during a single day because we spoke Polish to our neighbors, and we spoke German with children and with my husband we'd say: can you lyszować? [Original version: Bo sąsiedzi na przykład byli $z$ Gdańska, to tam musiałach zajś patrzeć, żeby mówić, móóówić, $i$ erstaunlicherweise wychodziło mi te pierwsze lata, ̇̇ech umiała to trennen, mówić, gołdać i sprechen, das waren manchmal drei verschiedene Sprachen am Tag, bo mit dem Nachbarn mówiliśmy, a z dziećmi gesprochen haben wir und mit meinem Mann das war ja: idzie to lyszować?] (NF_PAD)

In the last sentence, the verb lyszować 'to delete, erase' refers to the speaker's mixing languages when communicating with her husband. She gives this word as an example of mixing languages.

\section{Language practices pertaining to the next generation born in Germany}

While communication between spouses is spontaneous, German is consciously chosen for conversations with children. The same applies also to the children of close relatives, or the entire generation that was born in Germany. Only in isolated cases did one or both parents use Polish or Silesian in conversations with their children, either due to their insufficient competence in German

(30) And my wife always only in Polish. She doesn't speak German at all, so she [speaks Polish to children] [Original version: Und Frau immer nur Polnisch. Die spricht ja überhaupt nicht Deutsch, also.] (KI_WIM),

(31) Ah, with my son, we also had [an issue], I even talked to a pediatrician, because I really wanted Tomek to know Polish, because we still have family in Poland and so on. So I even talked to my pediatrician and said: Doctor, what would you say? Then he told me, this is a language for free, at home in Polish, and in kindergarten or whatever German, right. And so we did. [Original version: Ach mit dem Sohn das war auch so eine, ich hab sogar mit dem Kinderarzt gesprochen, weil ich wollte unbedingt, dass der Thomas polnische Sprache kennt, weil die Familie noch in Polen ist und so weiter. Und dann hab ich sogar mit meinem Kinderarzt gesprochen, habe ich 
gesagt, Herr Doktor, was sagen Sie denn? Da sagte er zu mir, das ist Sprache umsonst, zu Hause Polnisch, im Kindergarten oder wie auch immer Deutsch, ne. Und das haben wir auch so gemacht.] (KN_HAT)

The biographical interviews collected show that, in some cases, the spouses' speaking Silesian and Polish turned out to be sufficient for their children to acquire the ability to communicate in these languages. As a result, they can speak Polish or Silesian when visiting Poland, e.g.,:

(32) The children know Polish because my husband and I have spoken Polish all our lives and they can understand everything, every little thing. They can understand everything, but they didn't actively practice speaking, but they can understand everything, and whenever we came here to visit, they tried to speak Polish with cousins, sometimes they did a better job of it sometimes not, but they talked with them. [Original version: Dzieci znaja polski, bo $z$ mężem rozmawialiśmy całe życie po polsku i one wszystko rozumieja, wszyściusieńko. One wszystko rozumieja, tylko one czynnie nie ćwiczyly tej mowy, ale one wszystko rozumieja, a jak przyjechaliśmy tu zawsze na bezuch, to one z kuzynkami, to one próbowaty po polsku mówić, takjak im to wychodzito, tak wychodzito, ale mówity $z$ nimi.] (NF_PAD)

We know from interviews that some of the adult children of our informants have decided to learn or improve their Polish as part of study exchanges at universities in Poland, others on language courses, for instance, the daughter of one of the interviewees:

The younger daughter really wanted to learn Polish. And she even went, I think, she went for a Polish course in Germany a short while ago. [Original version: Młodsza córka bardzo chciała się nauczyć polskiego. I ona nawet chodziła, jeszcze chyba teraz przed krótkom chodzita na kurs polskiego $w$ Niemczech.] (NF_PAD)

The change of language in many families also pertained to the sphere of religion. Some immigrants have an opportunity to participate in masses in Polish, but they do not take advantage of it. Usually, the decision is made for practical reasons, one being the distance from the church and the other - the conviction that they can pray in German, so they are not interested in the mass in Polish. This is illustrated by one of the respondents from Lambrecht:

(34) We have [masses in Polish], but we don't do that. I've never done that and I don't want to do it now, because my children are altar servers and they serve mass every Sunday. This is the first reason, they also have friends in the altar 
servers group, and the second reason is the fact that I think I know German well enough to pray and sing in German and it's 15 min on foot [to the church], and I have to drive, I don't know, $20 \mathrm{~km}$ to go to the Polish mass, and on a Sunday afternoon to boot, so I have never been tempted, never attracted, never interested. [Original version: Des gibt's, aber das machen wir nicht. Das habe ich noch nie gemacht, das will ich auch nicht, durch dem, dass meine Kinder Messdiener sind und die gehen dann einfach jede Sonntag dienen. Das ist das erste Grund, da haben die auch dort Freunde von vom Messdienergruppe und zweite Gruppe, ich denk, ich kann so gut, so gut Deutsch, dass kann ich auch beten und singen auf Deutsch und da habe ich fünfzehn Minuten zum Fuß [...] und in der polnische muss ich dann was weiß ich zwanzig Kilometer mit Auto fahren, ist noch am Sonntag Nachmittag, also das hat mich nie gejuckt, nie gereizt, nie interessiert.] (LO_LAM)

The above quote features another important topic of children's participation in religious life. It is because of the children, first and foremost, that the respondent participates in masses in German. This is in line with the already mentioned policy of raising children in the majority language.

\section{The conceptualization of multilingualism}

The interviewees conceptualize their multilingualism as part of socially and politically grounded language ideologies. There are two main language ideologies in Europe that have been historically significant for the process of modernization and formation of nation-states in the seventeenth and eighteenth centuries. One is the belief in language standardization, and the other is monolingualism (Farr and Song 2011). According to these ideologies, which are mutually related and complement each other, an ideal person speaks one standardized language. The conviction about the value of monolingualism, and the resulting belief that multilingualism is harmful in education, is the reason for choosing the language of the state, the majority and socially dominant language, to communicate with children. That is why the immigrants from Silesia have spoken German with their children despite their poor language skills. The following illustrates the power of the ideology of monolingualism:

(35) For me, for example, when our children were born, it was important for me that our children had a good command of one language, and since I still had language deficiencies in German, it was important to me to polish this 
language together. [Original version: Bo u mnie było na przykład, jak nasze dzieci się urodzily, to mi było wichtig, żeby nasze dzieci jedna Sprache gut beherrscht haben, a przez to że ja jeszcze miatam braki językowe niemieckiego, to mi było wichtig, że my razem szlifujemy ta szprachę.] (NF_PAD)

(36) And for me, for example, it was very important not to mess with my children's heads, I didn't know, for example, if our children were linguistically gifted. Today I know that children can be raised in two or three languages, but at the time I didn't know that they could, that I could speak in two, three languages to my children, may be it is better, too, to learn the mother tongue first, to give the children language foundations in their native language. Because I didn't know if they were linguistically gifted, I thought, may be we should stick to one language, which helped me, and I suppose it helped the children as well, because they didn't have any problems at school. [Original version: I to mi na przykład bylo sehr wichtig, żeby dzieciom nie robić młynku w glowie, bo ja na przykład nie wiedziałam, czy nasze dzieci sa sprachlich begabt, dziecko się uczyło pierwszych. Heute weiß ich, dass man zwei Sprachen, dreisprachig kann man Kinder erziehen, ale $w$ damals wusste ich das noch gar nicht, że że moga, że moge dzieciom dwie, trzy szprachy mówić, vielleicht auch besser ist die Muttersprache als erste, żeby te te podstawy językowe mialy te dzieci in der Muttersprache. Przez to że nie wiedziatam, jak one, jak one, czy one sa sprachlich talentiert, dann hab ich gedacht, vielleicht bleiben wir bei einer Sprache, co mi to pomogto, a dzieciom przypuszczom też, że to pomogto, bo one nie miaty $\dot{z} a$ dnych, żadnych problemów $w$ szkole.] (NF_PAD)

The ideology of multilingualism was associated with the strong conviction about the need for assimilation:

(37) The family was of the opinion that since we've come here we need to adjust. When we were in Poland we spoke Polish, now we've come to Germany, we have adopted their nationality and customs. [Original version: Rodzina ma, jak to się mówi, jest tego zdania, przyjechaliśmy tutaj, więc trzeba się tutaj dostosować. Byliśmy w Polsce, to się mówito po polsku, przyjechaliśmy do Niemiec, przyjęliśmy ich narodowość, ich obyczaj.] (LO_LAM)

(38) I have entered, you could say, German circles or a group here that comes from Silesia and we started to speak German right away. [Original version: Weszłam raczej można powiedzieć $w$ środowisko niemieckie lub $w$ 
towarzystwo, które tutaj pochodziło ze Śląska i od razu zaczęliśmy próbować mówić językiem niemieckim.] (NO_LAM)

The interviewees express fears that they may be harassed because of speaking Polish:

Grandmother, grandfather did not want Polish to be spoken. They had kind of, they didn't want the neighbors to speak [ill about us] again. In Poland we were Goebbels, and here in turn we are Poles, they just wanted to adapt here, too. [Original version: Oma, opa tego nie chcieli, żeby się mówiło po polsku. Oni mieli jakiś taki, nie chcieli, żeby sąsiedzi znowu mówili, w Niemczech byliśmy Gebel, w Polsce byliśmy Goebbelsami, a tutaj znowu jesteśmy Polakami, chcieli się po prostu tu też dostosować.] (LO_LAM)

(40) We partied in Polish, but on the road, when we met and somebody could hear us, we spoke German. I think that this was our survival method not to be frowned upon so we would quickly speak German, and when we had a party among ourselves then we spoke Polish. [Original version: Tak: imprezy robiliśmy po polsku, ale na drodze, jak żeśmy się spotykali, jak ktoś mógł ustyszeć, to po niemiecku. [...] Das war unsere Überlebungsmethode, glaube ich, bo żeby ci drudzy krzywo nie patrzyli, tośmy szybko mówili po niemiecku, a jak żeśmy mieli imprezy unter uns, to żeśmy mówili po polsku.] (NF_PAD)

The interviewees have observed that the attitude towards bilingualism has changed recently. The following comments refer to changes in language ideologies and the formation of a positive image of bilingualism in Germany:

(41) Now it is also the case that these very, that is these people, typical Germans are now also of the opinion that it is better when people speak two or three languages. At the time when we left, they said: this one is from Poland. This attitude is gone. People have also evolved, their thinking has changed and now people say that, after all, language is important, whatever this language, and that's why I'm not ashamed to speak Polish anymore, also in public. I would do this. Because it has really changed now. [Original version: Jetzt ist es auch, dass die sehr, also die die Menschen, die typisch Deutsche die sind jetzt auch der Meinung, dass, es ist schöner, wenn Menschen zwei, drei Sprachen sprechen. Damals als wir gefahren sind, dann haben sie, der ist aus Polen, ne, das ist nicht mehr, nicht mehr dieses, die Leute haben sich auch entwickelt, die die, das Denken der Menschen hat sich entwickelt, dass man jetzt sagt, Sprache ist ja wichtig, egal welche 
Sprache und deswegen ich schäme mich jetzt nicht auch in der Öffentlichkeit Polnisch zu sprechen. Würde ich auch machen. Weil das hat sich jetzt wirklich verändert.] (NF_PAD)

As a consequence, some interviewees consider their decision to speak with their children only in German to be a mistake in retrospect:

(42) Earlier, at the beginning, when they were little, somehow one thought that it would be better to speak only German first, because one often heard that children who start German later have problems at school and so on. For this reason, we said ok, we will do only one thing. Looking back, it might also have been a mistake. May be we could have done it better because once, I don't know exactly how old they were then, twelve, thirteen or fourteen. Suddenly, they began to speak Polish on their own. Or at least a few words and they could understand it too. [Original version: Ja gut, früher, also Anfang, wo sie klein waren, hat man das irgendwie Mal gemeint, es ist besser, wenn man nur erst nur Deutsch spricht, damit sie ja auch manchmal oft gehört hatte, dass dass jetzt mal Kinder, die erst später mit der deutschen Sprache anfangen, dass sie dann ihre Problemchen haben in der Schule und so weiter. Aus dem Grunde haben wir gesagt ok, wir machen's halt nur das. Und wenn man das im Nachhinein betrachtet war das schon vielleicht auch ein Fehler. Vielleicht hätt man das auch besser, weil irgendwann, weiß zwar nicht genau, wie sie wie alt sie damals waren, ob so zwölf, dreizehn oder vierzehn. Auf einmal haben sie angefangen selber Polnisch zu sprechen ja. Oder zumindest einige Wörter und haben's auch verstanden.] (HM_STE)

\section{Conclusion}

The article presents the impact of language ideologies and language policies on the change of the language of immigrants from Silesia living in Germany. Language ideologies are systems of beliefs about language widely acknowledged in a given society, and the most widespread of which are unquestioned (Chromik 2014: 69; Wolfram 1998: 109). Ideologies operate as a doxa - the convictions and truths, or conventional opinions, about what the social order should be, that are believed to be natural and binding, therefore they are neither discussed nor examined, they are taken for granted. Language ideologies have causative power; they can determine whether a language will be preserved or lost and even affect its structures (Chromik 2014: 68; Jaffe 1999). In this way, language ideologies are a bond between social structures and language. They influence the formation of 
the social standard of linguistic behavior in multilingual communities. They determine the value of languages and classify them as correct or incorrect. Moreover, whether or not a person speaks correctly determines how they feel. Brigitta Busch has introduced the term Spracherleben, 'lived experience of language,' to linguistics (2013: 18-20). Lived experience of language is related to the emotions felt when communicating in a language: does a person feel fully themselves then, or do they have the impression that they are an actor on stage, or another person? Do they feel accepted or, the other way round, they feel ashamed and fear rejection? Do they feel strong and efficient, or rather weak and ineffective? Busch points out that the emotional experience of language use has been a neglected aspect of studies on multilingualism, as researchers have rather focused their attention on language competence and other measurable parameters. Each lived experience of language is individual and arises in a particular situation.

In this paper the material collected makes it possible to distinguish the main themes and topics that recur in many autobiographical narratives, including those of lived experience of language. The interviews with immigrants from Upper Silesia share several narrative themes which are important to the interviewees because they are always related to their personal encounters, experiences and feelings. That is why the stories about language experiences are turning points in language biographies.

The first topic recurring in the interviews concerns the language change that occurred in the generation of their grandparents and parents after 1945. This change was an outcome of historical and social circumstances in which the territory where they lived had been transferred from one state to another, at the same time their language change occurred in traumatic post-war conditions of coercion and terror. Language policy is a system of laws and rules implementing language ideologies that are desirable from the point of view of the authorities, and the goal of state language policy at that time was to eliminate German quickly and completely. Therefore top-down language management was performed through intimidation, punishment, and discrimination against German speakers. As a result German-speaking inhabitants of Silesia decided to rapidly change the language spoken in their families. This resulted in intergenerational language transmission being interrupted.

The second topic concerns the lack of knowledge of German. The immigrants leaving for Germany did not know the language of their ancestors and learning German at language courses did not ensure full and satisfactory command of the language. For this reason, in the first phase of their stay in Germany, the dominant feeling associated with language was shame. The immigrants sought full assimilation with German society, and their lack of perfect command of German was a 
serious obstacle in these endeavors. Thus, the ideology of monolingualism was in line with the ideology of assimilation. The third topic is language planning focusing on children. Teaching children German was the goal of language management in families. That is why the immigrants, although they had not mastered the language themselves, spoke German to their children. Paradoxically, they passed on a language they had only recently learned while not seeking to pass on Polish or Silesian, in which they were raised themselves, to the younger generation.

The collected biographical interviews show that language change is associated with the change of state and of the state language, and results from the hegemony of language ideologies which combine nationality and loyalty to the state with the use of one majority language. There is a significant difference between the change of the language from German to Silesian or Polish in the Silesian community in Poland after 1945, and the change of the language from Silesian and Polish to German after emigration to Germany. The former was a top-down change, initiated and organized by state authorities using brutal methods. The participants were forced to change their language. On the other hand, the change of language in Germany was a bottom-up change initiated by the bilingual speakers themselves with state support. The dramatic history of the families surveyed has come full circle because they have returned to communicating in German.

\section{List of informants quoted}

$\begin{array}{ll}\text { LX_GEM } & \text { male living in Gemmingen, born in Koźle in 1960, he left in } 1988 \\ \text { XL_MÜN } & \text { male living in München, born in Prudnik in 1964, he left in } 1987 \\ \text { KI_WIM } & \text { male living in Wimbuch, born in Koźle in 1968, he left in 1991 } \\ \text { SO_LAM } & \text { male living in Lambrecht, born in Polska Cerekiew in 1964, he left in } 1991 \\ \text { LO_LAM } & \text { female living in Lambrecht, born in Koźle in 1970, she left in 1990 } \\ \text { BN_WUP } & \text { male living in Wuppertal, born in Biedrzychowice in 1964, he left in } 1990 \\ \text { KL_BIE } & \text { male living in Bielefeld, born in Gtogówek in 1962, he left in 1988 } \\ \text { NF_PAD } & \text { female living in Paderborn, born in Krapkowice in 1968, she left in } 1990 \\ \text { NT_LÜB } & \text { male living in Lübeck, born in Koźle in 1961, he left in 1981 } \\ \text { CL_BIE } & \text { female living in Bielefeld, born in Gtogówek in 1965, she left in } 1979 \\ \text { KN_HAT } & \text { female living in Hattingen, born in Gtogówek in 1965, she left in } 1989 \\ \text { HM_STE } & \text { male living in Steinen, born in Gtogówek in 1965, he left in 1988 } \\ \text { LU_KOŹ } & \text { male living in Kędzierzyn-Koźle, born in Cosel in 1940 } \\ \text { SL_OPO } & \text { female living in Opole, born in Oppeln in 1939 }\end{array}$

Research funding: The paper was written within the framework of the research project entitled Language across generations: Contact induced change in morphosyntax in German-Polish bilingual speech, financed by the National Science Centre, 
Poland, project no. 2016/23/G/HS2/04369, carried out at the Institute of Slavic Studies, Polish Academy of Sciences.

\section{References}

Busch, Brigitta. 2013. Mehrsprachigkeit. Wien: UTB, Facultas.

Busch, Brigitta. 2015. Expanding the notion of the linguistic repertoire: On the concept of Spracherleben - the lived experience of language. Applied Linguistics 38/3. 340-358. (accessed 10 December 2020).

Busch, Brigitta. 2016. Methodology in biographical approaches in applied linguistics. Paper 187. Working papers in Urban language \& literacies, 1-12.

Choroś, Monika. 2015. Język, dialekt, gwara, godka. In Bernard Linek \& Andrzej Michalczyk (eds.), Leksykon mitów, symboli i bohaterów Górnego Śląska XIX-XX wieku, 69-72. Opole: Państwowy Instytut Naukowy - Instytut Śląski w Opolu.

Chromik, Bartłomiej. 2014. Aspekty pojęcia ideologie językowe istotne z perspektywy działań rewitalizacyjnych. Zeszyty Łużyckie 48. 65-76.

Dawid, Adriana. 2020. Niepolskie Opolskie. Wtadze polityczne i administracyjne oraz apparat bezpieczeństwa wobec proniemieckich postaw mieszkańców województwa opolskiego (19501956). Opole: Wydawnictwo Uniwersytetu Opolskiego.

Dietz, Barbara. 2011. Aussiedler/Spätaussiedler in Germany since 1950. In Klaus J. Bade, Pieter C. Emmer, Leo Lucassen \& Jochen Oltmer (eds.), The encyclopedia of migration and minorities in Europe: From the seventeenth century to the present, 245-250. Cambridge: Cambridge University Press.

Farr, Marcia \& Juyoung Song. 2011. Language ideologies and policies: Multilingualism and education. Language and Linguistics Compass 5/9. 650-665.

Fishman, Joshua. 1964. Language maintenance and language shift as a field of inquiry: A definition of the field and suggestions for its further development. Linguistics 2(9). 32-70.

Fishman, Joshua A. 1971. The sociology of language: An interdisciplinary social science approach to language in society. In Joshua A. Fishman (ed.), Advances in the sociology of language, 217-404. The Hague: Mouton.

Franceschini, Rita \& Johanna Miecznikowski. 2004. „Wie bin ich zu meinen verschiedenen Sprachen gekommen?” Ein Vorwort. In Rita Franceschini \& Johanna Miecznikowski (eds.), Leben mit mehreren Sprachen. Sprachbiographien/Vivre avec plusieurs langues. Biographies langagières, VII-XXI. Bern, Berlin: Peter Lang.

Gajda, Stanistaw. 2001. System odmian i jego dynamika rozwojowa. In Stanisław Gajda (eds.), Najnowsze dzieje języków słowiańskich. Język polski, 207-219. Opole: Uniwersytet Opolski Instytut Filologii Polskiej.

Głuszkowski, Michał. 2011. Socjologiczne i psychologiczne uwarunkowania dwujęzyczności staroobrzędowców regionu suwalsko-augustowskiego, Toruń: Wydawnictwo Naukowe Uniwersytetu Mikołaja Kopernika.

Gudaszewski, Grzegorz. 2015. Struktura narodowościowo-etniczna, językowa i wyznaniowa ludności Polski. Narodowy Spis Powszechny Ludności i Mieszkań 2011. Warszawa: GUS. https://stat.gov.pl/spisy-powszechne/nsp-2011/nsp-2011-wyniki/struktura-narodowoetniczna-jezykowa-i-wyznaniowa-ludnosci-polski-nsp-2011,22,1.html (accessed 26 February 2020). 
Hanich, Andrzej. 2008. Wprowadzenie języka polskiego do duszpasterstwa na Śląsku Opolskim w 1945 roku. In Śląsk w polsko-niemieckiej i europejskiej wspólnocie interesów: XII Seminarium Śląskie, Kamień Śląski 2007. Języki Ślązaków: wczoraj, dziś, jutro, 52-68. Gliwice, Opole: Dom Wspótpracy Polsko-Niemieckiej.

Hentschel, Gerd. 2018. Śląski: gwara - dialekt - język? Spojrzenie z zewnątrz. In Jolanta Tambor (ed.), Pogranicza, mniejszości, regiony. Etnolingwistyka, 41-66. Katowice: Wydawnictwo Uniwersytetu Śląskiego.

Hoffman, Eva. 1998. Lost in translation: A life in new language. London: Vintage.

Jaffe, Alexandra. 1999. Ideologies in action. Language politics on Corsica. Berlin: De Gruyter Mouton. Jaroszewicz, Henryk. 2019a. Krytyka prób emancypacji śląszczyzny. Płaszczyzna prawnoustrojowa, społeczno-polityczna i personalna. Slavica Wratislaviensia 169.137-166.

Jaroszewicz, Henryk. 2019b. Rozwój języka Górnoślązaków w XXI w. Szkic socjolingwistyczny. Zeszyty Łużyckie 53. 25-42.

Kacprzak, Paweł. 2010. Polityka władz polskich wobec ludności niemieckiej w okresie funkcjonowania Ministerstwa Ziem Odzyskanych. Czasopismo prawno-historyczne LXII/2. 215-235.

Kamusella, Tomasz. 2011. Silesian in the nineteenth and twentieth centuries: A language caught in the net of conflicting nationalisms, politics, and identities. Nationalities Papers 39(5). 769-789.

Kamusella, Tomasz. 2016. Silesian: From Gwara to language after 1989. Rocznik Polsko-Niemiecki 24(1). 78-119.

Karch, Brendan. 2018. Nation and loyalty in a German-Polish borderland: Upper Silesia, 18481960. Cambridge; New York: Cambridge University Press.

Kaufmann, Jean-Claude. 2016. L'entretien compréhensif. Paris: Armand Colin.

Kneip, Matthias. 2000. Die deutsche Sprache in Oberschlesien. Untersuchungen zur politischen Rolle der deutschen Sprache als Minderheitensprache in den Jahren 1921-1998. Dortmund: Forschungsstelle Ostmitteleuropa.

Kohli, Martin. 1981. Zur Theorie der biographischen Selbst- und Fremdthematisierung. In Joachim Matthes (ed.), Lebenswelt und soziale Probleme: Verhandlungen des 20. Deutschen Soziologentages zu Bremen 1980, 502-520. Frankfurt am Main: Campus Verl. https://nbnresolving.org/urn:nbn:de:0168-ssoar-188363 (accessed 10 December 2019).

Kroll, Jan \& Włodzimierz Kalicki. 1991. Jestem Ślązakiem i Niemcem. Z Janem Krollem, liderem Stowarzyszenia Mniejszości Niemieckiej na Śląsku Opolskim rozmawia Włodzimierz Kalicki. Przegląd Zachodni 2. 128-135.

Księżyk, Felicja. 2017. Die deutschen Sprache in Oberschlesien am Beispiel des Sprachinseldeutschen von Kostenthal/Gościęcin. Zeitschrift für Dialektologie und Linguistik LXXXIV(1). 20-45.

Księżyk, Felicja. Rekonstruktion von Identität in oberschlesischen Sprachbiographien. Die Welt der Slaven, in press.

Kurpiers, Dorota. 2015. Górnośląska pobożność. In Bernard Linek \& Andrzej Michalczyk (eds.), Leksykon mitów, symboli i bohaterów Górnego Śląska XIX-XX wieku, 73-76. Opole:

Państwowy Instytut Naukowy - Instytut Śląski w Opolu.

Lasatowicz, Maria Katarzyna, Tobias Weger. 2008. Polen. In Ludwig M. Eichinger, Albrecht Plewnia \& Claudia Maria Riehl (eds.), Handbuch der deutschen Sprachminderheiten in Mittel- und Osteuropa, 145-169. Tübingen: Narr.

Leopold, Werner F. 1939-1949. Speech development of a bilingual child. A linguist's record (4 volumes). Evanston: Northwestern University Press. 
Linek, Bernard. 1997. „Odniemczanie” województwa śląskiego w latach 1945-1950 (w świetle materiatów wojewódzkich). Opole: Wydawnictwo Instytut Śląski.

Linek, Bernard. 2000. Polityka antyniemiecka na Górnym Śląsku w latach 1945-1950. Opole: Stowarzyszenie Instytut Śląski; Państwowy Instytut Naukowy - Instytut Śląski w Opolu.

Linek, Bernard. 2015. Górny Śląsk - Horní Slezsko - Oberschlesien: próba osadzenia terytorium w czasoprzestrzeni kulturowej. In Bernard Linek \& Andrzej Michalczyk (eds.), Leksykon mitów, symboli i bohaterów Górnego Śląska XIX-XX wieku, 379-383. Opole: Państwowy Instytut Naukowy - Instytut Śląski w Opolu.

Madajczyk, Piotr (ed.) 1998. Mniejszości narodowe w Polsce. Państwo i spoteczeństwo polskie a mniejszości narodowe w okresach przełomów politycznych (1944-1989). Warszawa: Instytut Studiów Politycznych Polskiej Akademii Nauk.

Madajczyk, Piotr \& Danuta Berlińska. 2008. Polska jako państwo narodowe: historia i pamięć. Warszawa \& Opole: Instytut Studiów Politycznych Polskiej Akademii Nauk - Państwowy Instytut Naukowy - Instytut Śląski.

Matuschek, Herbert. 1997. Das Polnisch der Oberschlesier. Zu den Kontroversen um ein Idiom. Oberschlesisches Jahrbuch 13. 93-119.

Meng, Katharina. 2004. Russlanddeutsche Sprachbiographien - Rückblick auf ein Projekt. In Rita Franceschini \& Johanna Miecznikowski (eds.), Leben mit mehreren Sprachen. Sprachbiographien/Vivre avec plusieurs langues. Biographies langagières, 97-117. Bern, Berlin: Peter Lang.

Michna, Ewa. 2019. Emancypacja śląszczyzny w kontekście „starych” i „nowych” ideologii językowych. Postscriptum Polonistyczne 1(23). 57-76.

Nekula, Marek. Sprachideologien und Sprachmanagement in sprachbiographischen Interviews mit Sprechern mit tschechischem Migrationshintergrund in Bayern. In Bernhard Brehmer \& AnnaLena Klatt (eds.), Multilinguale SprachBioGraphien in Mittelosteuropa. Frankfurt am Main: Peter Lang, in press.

Nekvapil, Jiři \& Tamah Sherman. 2015. An introduction: Language management theory in language policy and planning. International Journal of the Sociology of Language 2015(232). 1-12.

Ogiolda, Krzysztof. 2018. Mniejszość niemiecka nie jest jeziorem, które wyschło, ale świeżej wody potrzebuje. Nowa Trybuna Opolska. 6 July 2018. 18-19.

Piller, Ingrid. 2016. Linguistic diversity and social justice: An introduction to applied sociolinguistics. Oxford: Oxford University Press.

Preisner, Johannes. 2009. Friedersdorf. Kreis Neustadt OS. Die Entwicklung eines oberschlesischen Dorfes von seinen Anfängen bis 1945. 5. verbesserte und ergänzte Auflage. Menden: Historische Kommission für den Kreis Neustadt/Oberschlesien e.V.

Ronjat, Jules. 1913. Le développement du langage observé chez un enfant bilingue. Paris: Champion.

Rosenthal, Gabriele. 1995. Erlebte und erzählte Lebensgeschichte: Gestalt und Struktur biographischer Selbstbeschreibungen. Frankfurt/Main: Campus Verlag.

Rosenthal, Gabriele. 2006. The narrated life story: On the interrelation between experience, memory and narration. In Kate Milnes, Christine Horrocks, Nancy Kelly, Brian Roberts \& David Robinson (eds.), Narrative, memory \& knowledge: Representations, aesthetics, contexts, 1-16. Huddersfield: University of Huddersfield.

Schütze, Fritz. 1983. Biographieforschung und narratives interview. Neue Praxis 13(3). 283-293. https://nbn-resolving.org/urn:nbn:de:0168-ssoar-53147 (accessed 10 December 2019).

Silverstein, Michael. 1979. Language structure and linguistic ideology In Paul R. Clyne, William F. Hanks \& Carol L. Hofbauer (eds.), The elements: $A$ parasession on linguistic units and levels, 193-247. Chicago: Chicago Linguistic Society. 
Turner, Jonathan H. 2012. Theoretical principles of sociology. In Mesodynamics, Vol. 3, 1-27. New York, Heidelberg, Dordrecht, London: Springer.

Turska, Halina. 1995. O powstaniu polskich obszarów językowych na Wileńszczyźnie $=0$ proishoždenii pol'skoâzyčnyh arelov v Vil'nûsskom krae. Vilnius: Mintis.

Wierzbicka, Anna. 1990. Podwójne życie człowieka dwujęzycznego. In Władysława Miodunka (ed.), Język polski w świecie. Zbiór studiów, 71-104. Warszawa-Kraków: Państwowe Wydawnictwo Naukowe.

Wierzbicka, Anna. 1997. Moje podwójne życie: dwa języki, dwie kultury, dwa światy. Teksty Drugie: teoria literatury, krytyka, interpretacja nr 3(45). 73-93.

Wiesinger, Peter. 1983. Die Einteilung der deutschen Dialekte. In Werner Besch, Ulrich Knoop, Wolfgang Putschke \& Herbert Ernst Wiegand (eds.), Dialektologie. Ein Handbuch zur deutschen und allgemeinen Dialektforschung, 801-900. Berlin, New York: Walter de Gruyter.

Wolfram, Walt. 1998. Language ideology and dialect. Understanding the Oakland ebonics controversy. Journal of English Linguistics 26(2). 108-121.

Wyderka, Bogusław. 2018. 0 standaryzacji języka śląskiego. Kwartalnik Opolski 1. 3-18.

Znaniecki, Florian and William I. Thomas. 1996. The Polish peasant in Europe and America: A classic work in immigration history. In Eli Zaretsky. Urbana, Ill.: University of Illinois Press. 